\title{
Current management strategies to target the increasing incidence of diabetes within Pakistan [Corrigendum]
}

\author{
Basit A, Fawwad A, Siddiqui SA, Baqa K. Diabetes \\ Metab Syndr Obes. 2019;12:85-96.
}

Page 96, Reference 57, it has come to the attention of the authors that reference 57 was formatted incorrectly. The cor- rect reference should read "57. Hussain A, Ali I. Diabetes mellitus in Pakistan: a major public health concern. Arch Pharm Pract. 2016;7(1):30-32."

\section{Publish your work in this journal}

Diabetes, Metabolic Syndrome and Obesity: Targets and Therapy is an international, peer-reviewed open-access journal committed to the rapid publication of the latest laboratory and clinical findings in the fields of diabetes, metabolic syndrome and obesity research. Original research, review, case reports, hypothesis formation, expert opinion and commentaries are all considered for publication. The manuscript management system is completely online and includes a very quick and fair peer-review system, which is all easy to use. Visit http://www.dovepress.com/testimonials.php to read real quotes from published authors. 